\title{
Hospital Nurse Scheduling Optimization Using Simulated Annealing and Probabilistic Cooling Scheme
}

\author{
Ferdi Chahyadi $^{* 1}$, Azhari $^{2}$, Hendra Kurniawan ${ }^{3}$ \\ 1,3 Jurusan Teknik Informatika, Universitas Maritim Raja Ali Haji, Tanjungpinang, Indonesia \\ ${ }^{2}$ Departemen Ilmu Komputer dan Elektronika, FMIPA UGM, Yogyakarta, Indonesia \\ e-mail: *11 ferdi.chahyadi@umrah.ac.id, ${ }^{2}$ arisn@ugm.ac.id, ${ }^{3}$ hendra@umrah.ac.id
}

\begin{abstract}
Abstrak
Penjadwalan kerja perawat di rumah sakit merupakan permasalahan yang kompleks dan memerlukan waktu yang lama dalam proses pembuatannya. Banyak batasan-batasan atau aturan yang harus dipertimbangkan dalam proses pembuatan jadwal kerja perawat agar bisa memenuhi kebutuhan preferensi perawat yang bisa meningkatkan kualitas dari pelayanan. Adanya berbagai macam faktor yang berbeda-beda tersebut menyebabkan masalah penjadwalan perawat begitu luas dan berbeda di setiap kasus.

Penelitian ini mengembangkan sistem yang digunakan sebagai alat bantu untuk melakukan penjadwalan kerja perawat. Jadwal kerja yang dihasilkan akan diperiksa sesuai batasan-batasan (constraint) yang telah ditentukan. Pemeriksaan nilai pelanggaran terhadap constraint menggunakan metode Simulated Annealing (SA) yang dikombinasikan dengan metode pendinginan Probabilistic Cooling Scheme (PCS). Aturan transisi dengan matrik biaya digunakan untuk menghasilkan state baru yang lebih efisien.

Hasil yang diperoleh menunjukkan metode pendinginan PCS yang dikombinasikan dengan aturan transisi terhadap matrik biaya menghasilkan nilai fungsi objektif solusi baru yang lebih baik dan waktu proses yang lebih cepat daripada metode pendinginan eksponensial dan logaritmik. Jadwal kerja yang dihasilkan oleh aplikasi juga memiliki kualitas lebih baik daripada jadwal yang dibuat secara manual oleh kepala ruang.
\end{abstract}

Kata kunci-Penjadwalan Perawat, Simulated Annealing, Matrik Biaya, PCS

Nurse's scheduling in hospitals becomes a complex problem, and it takes time in its making process. There are a lot of limitation and rules that have to be considered in the making process of nurse's schedule making, so it can fulfill the need of nurse's preference that can increase the quality of the service. The existence variety of different factors that are causing the nurse scheduling problem is so vast and different in every case.

The study is aimed to develop a system used as an equipment to arrange nurse's schedule. The working schedule obtained will be checked based on the constraints that have been required. Value check of the constraint falsification used Simulated Annealing (SA) combined with cooling method of Probabilistic Cooling Scheme (PCS). Transitional rules used cost matrix that is employed to produce a new and more efficient state.

The obtained results showed that PCS cooling methods combined with the transition rules of the cost matrix generating objective function value of new solutions better and faster in processing time than the cooling method exponential and logarithmic. Work schedule generated by the application also has a better quality than the schedules created manually by the head of the room.

Keywords-Nurse's Scheduling, Simulated Annealing, Cost Matrix, PCS

Received March 16 ${ }^{\text {th }}, 2017$; Revised May $9^{\text {th }}, 2017$; Accepted January $3^{\text {rd }}, 2018$ 


\section{INTRODUCTION}

Hospital nurses scheduling is a very complex problem, because there are many restriction and rules must be achieved. In every work shift schedule it should be ensured that there are sufficient number of nurses to perform the task at all time. With these different factors, the nurse's scheduling problem is so complex and unique in each shift case. Hospital nurse's work scheduling has two limitations, namely hard constraint and soft constraint [1]. Hard constraints constitute limits in the form of defined rules in the formation of nurse schedules, whereas soft constraints are to improve the quality of scheduling result, thus minimizing schedule violation.

A study of nurse work scheduling using Simulated Annealing was performed in 2008. The styudy explained performance of Simulated Annealing has better ability than Genetic Algorithm, the value of violation to constraint is smaller and the processing time is shorter compare to Genethic Algoritm[2]. Simulated Annealing (SA) is a metaheuristic method for solving combinatorial problems using analogy of annealing processes in solids [3]. Objective of this work is to develop a system for nurse scheduling using Simulated Annealing method with additional state transition rules to search for new solutions with various constraints. Scheduling problem will be represented in a cost matrix, and then will be evaluated using the objective function. The objective function is an evaluation of the cost function of the schedule matrix to model the ideality level of a scheduling solution generated based on the value of penalties obtained from hard constraints and soft constraints. The objective function then applied a transition rule with a certain probability by considering the cost matrix to produce a new state on a schedule. The Probabilistic Cooling Scheme (PCS) technique utilizing the features of logarithmic and exponential cooling schedules will be applied to the Simulated Annealing algorithm.

\section{METHODS}

The research is divided into several stages, briefly in Figure 1.

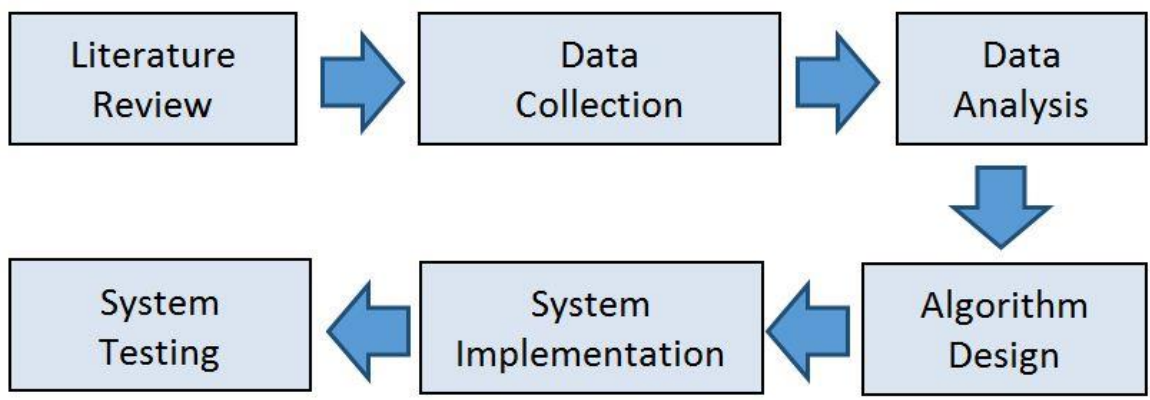

Figure 1 Research Flow Diagram

Figure 1 describes the stages of research that begins with literature study, data collection followed by nurse job scheduling analysis, then simulated annealing algorithm is designed based on previous data analysis, finally designing and testing the system.

\subsection{Scheduling}

Scheduling is an allocation number of subjects into a certain period to satisfy the constraints provided by fulfilling as many restrictions as possible. Scheduling issues have several types, such as sport events scheduling, staf scheduling, course scheduling, laboratory work scheduling, etc. Scheduling problems are represented as combinatorial optimization problem commonly referred to as NP-hard [4].

IJCCS Vol. 12, No. 1, January 2018: $21-32$ 


\subsection{Nurses Scheduling}

Ideal nurse scheduling is a scheduling that can achieved all the hard constraints and has a minimal violation value against the soft constraints to improve the performance and quality of nursing services to handle patients [5]. Nurses scheduling can be implemented by addressing monthly schedules of $\mathrm{N}$ nurses by assigning nurses to one shift that can be represented as a matrix $\mathrm{x}$ with $\mathrm{NxD}$ dimension where $\mathrm{N}$ is the number of nurses and $\mathrm{D}$ is the number of days. So $\mathrm{Xij}$ is an element in the matrix that states nurse $\mathrm{i}$ work on day $\mathrm{j}$ as described in Figure 2.

$$
X=\left[\begin{array}{cccccc}
X_{11} & X_{12} & \ldots & X_{1 j} & \ldots & X_{1 d} \\
X_{21} & X_{22} & \ldots & X_{2 j} & \ldots & X_{2 d} \\
\vdots & \vdots & \vdots & \vdots & \vdots & \\
X_{i 1} & X_{i 2} & \ldots & X_{i j} & \ldots & X_{i d} \\
X_{n 1} & X_{n 2} & \ldots & X_{n j} & \ldots & X_{n d}
\end{array}\right]
$$

Figure 2 Matrix notation of nurse scheduling

\subsection{Simulated Annealing}

Simulated Annealing (SA) is a variant of the Heuristic Search Hill Climbing technique where this variation is the opposite of Steepest Hill Climbing [6]. In minimization case problems, an effective way of not being trapped into local minimums is to allow a step toward a state that has a cost greater than the current state. SA algorithm implement this procedure, where the selection of new state is performed randomly with a certain probability. If the new state is better than the current state, then SA always selects the new state. However, if the new state is worse than the current state, then the new state may still be selected using equation (1) and the acceptance condition of the new state based on the probability function using equation (2) [7].

$$
P(\Delta E)=e^{-\frac{\Delta E}{T}}
$$

where

$\Delta E \quad=$ Delta energy

$\mathrm{T} \quad=$ Initial Temperatur value

$$
C_{0}=\left\{\begin{array}{l}
C_{0+1}, \text { if } \mathrm{P}(\Delta \mathrm{E})>\mathrm{r} \\
C_{0}, \text { if } \mathrm{P}(\Delta \mathrm{E})<\mathrm{r}
\end{array}\right.
$$

where

$\mathrm{C}_{0} \quad=$ Current Sollution

$\mathrm{P}(\Delta \mathrm{E})=$ Solution acceptance probability

$\mathrm{r} \quad=$ Random value between 0 and 1

How to decrease the temperature is a very important and critical in Simulated Annealing. There are two ways that can be used, namely: 1) by doing a large number of iterations at little temperature and a small amount of iteration at many temperatures or 2) using a balanced portion between the two. One way to lower the temperature is to use the logarithmic method [8]. Adjusted to the logarithmic method, as shown in equation (3).

$$
T_{k}=\frac{\alpha \cdot T_{0}}{\ln (2+k)}
$$

$T_{k}$ is temperature value at $\mathrm{k}$-iteration, and $\mathrm{k} \in\{1 \ldots 100\} . T_{0}$ is initial temperature value and is cooling process speed parameter. Logarithmic cooling schedule has been demonstrated to reach 
global minimum when $=1$ but takes a very long time in the process. Equation (4) shows temperature decrease using exponential method.

$$
\mathrm{T}(\mathrm{k})=\mathrm{T}_{0} * \alpha^{\mathrm{k}}
$$

where $\quad=0.95$. Exponential methods can produce very rapid temperature drop [9].

There are several ways to measure the quality of the solution. Generally the quality of the solution is measured using the cost function. SA is designed for minimization problems, so the smaller the cost function of a state means the better the quality of the state. To build cost function, we can give weighting. Hard constraints may be given a large weight so that many solutions violate them will have a high cost function. While soft constraints are given weight that corresponds to the level of importance. The formulation of the cost function by weighting is formulated using equation (5) [10].

$$
f=\sum_{i=1}^{N} C_{i} W_{i}
$$

where :

$\mathrm{C}_{\mathrm{i}} \quad$ : number of violations at constraint $i$-th

$\mathrm{W}_{\mathrm{i}} \quad$ : weighting value for constraint $i$-th

$\mathrm{N} \quad$ : number of constraint

\subsection{System Architecture}

In this research Simulated Annealing method will be used with combination to Probabilistic Cooling Scheme (PCS) cooling scheme. Combination of SA and PCS will generate one month hospital nurses scheduling. In this study the transition rule is applied to produce more efficient state. There are three main types of shifts that will be scheduled for the nurse, morning shift $(\mathrm{M})$, evening shift $(\mathrm{E})$, and night shift $(\mathrm{N})$. In addition, there is also a day off schedule $(\mathrm{O})$ that will be included in the scheduling process. As for nurse schedule preference, nurses can choose between $\mathrm{M} / \mathrm{E} / \mathrm{N} / \mathrm{O}$ shifts on certain days. There are also preference options for leave schedule (C), maternity leave (CM), and public holidays (LU).

This section will explain the concept of hospital nurse scheduling using Simulated Annealing method. Initial conditions, stopping conditions, and limitations in scheduling will be defined first such as hard constraints and soft constraints. Initialization of the schedule is determined randomly by considering nurse schedule preference data. The initial schedule saved into the database. The initial schedule then will be displayed for the next proces and will be used for scheduling process using Simulated Annealing. The initial schedule will be checked according to the constraints that have been defined previously and violation value of each constraints will be recorded.

Objective function is calculated using violation values that have been obtained and cost matrix is generated to calculate a new state solution value. Final schedule will be generated after stop condition achieved, then final schedule is stored into the database replacing the initial schedule. The whole process is outlined in Figure 3.

IJCCS Vol. 12, No. 1, January 2018: $21-32$ 


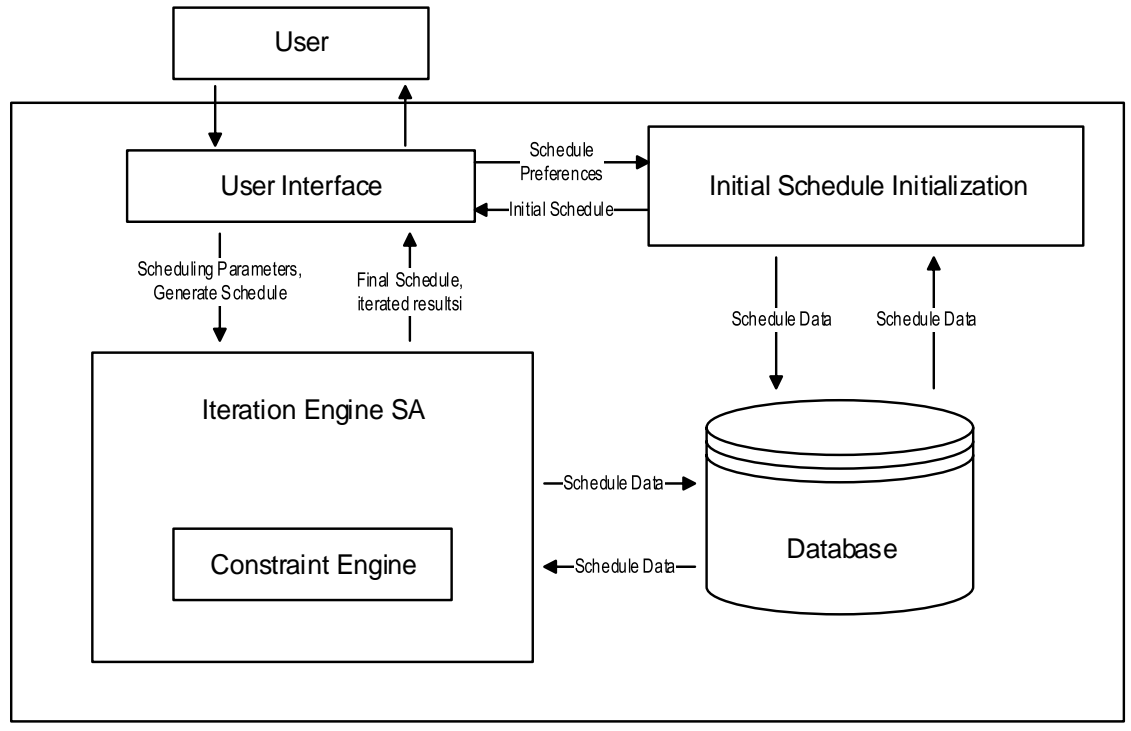

Figure 3 Nurse scheduling system

\subsection{Simulated Annealing Algorithm for Nurse Scheduling}

Design of the Simulated Annealing algorithm for nurse scheduling is shown in Figure 4.

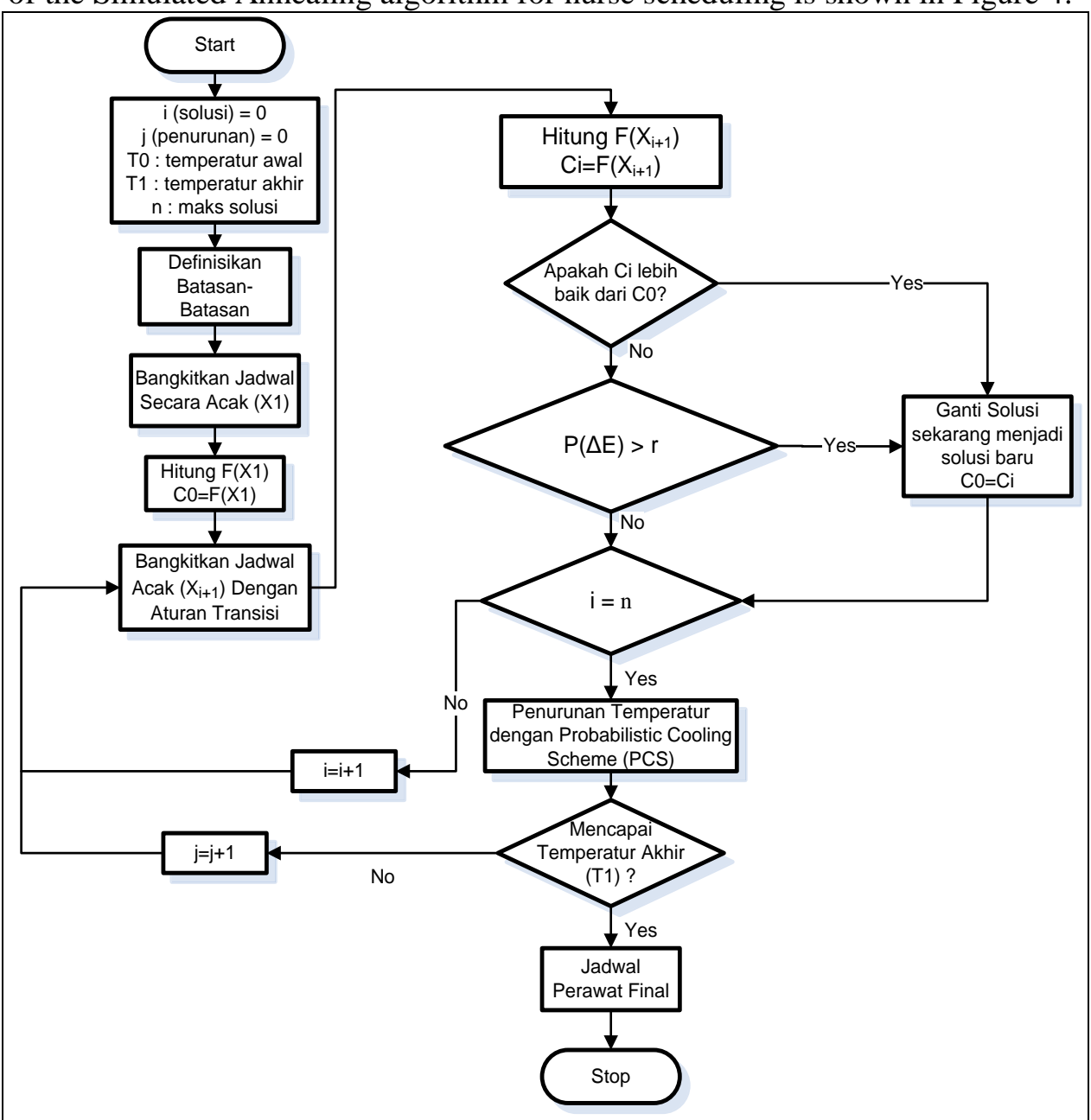

Figure 4 Simulated Annealing Algorithm for nurse scheduling 
In Figure 4 the process begins with initialization of the initial parameters, the constraints required for processing then result in a full-time work schedule.

\subsubsection{Hard Constraint}

a. Number of nurses for each shift should be in the minimum and maximum range number of nurses on duty :

- Morning shift $(\mathrm{M})$ : minimum 5 nurses, maximum 8 nurses.

- Evening shift $(\mathrm{E})$ : minimum 5 nurses, maximum 7 nurses.

- $\quad$ Night shift $(\mathrm{N})$ : minimum 5 nurses, maximum 7 nurses.

Where $m_{j}, e_{j}, n_{j}$ is number of nurses on duty for shift $\mathrm{m}, \mathrm{e}, \mathrm{n}$ at day $j$-th consecutively. If the number of nurses on duty is not within the minimum and maximum range of each shift, morning shift $\left(\mathrm{m}_{\min }, \mathrm{m}_{\max }\right)$, evening shift $\left(\mathrm{e}_{\min }, \mathrm{e}_{\max }\right)$, and night shift $\left(\mathrm{n}_{\min }, \mathrm{n}_{\max }\right)$, then cost value $\mathrm{C}_{1}$ is equal to 1 as shown in equation (6).

where :

$$
C_{1}=\sum_{j=1}^{D}\left(c m_{j}+c e_{j}+c n_{j}\right)
$$

$\mathrm{cm}_{j} \quad$ : Cost for $m$ at day $j$-th, 0 if $m_{\min } \leq m_{j} \leq m_{\max }$ else 1

$c e_{j} \quad:$ Cost for $e$ at day $j$-th, 0 if $e_{\min } \leq e_{j} \leq e_{\max }$ else 1

$c n_{j} \quad$ : Cost for $n$ at day j-th, 0 if $n_{\min } \leq n_{j} \leq n_{\max }$ else 1

b. Work patterns to avoid :

- Nurse working at night shift $(\mathrm{N})$ at day $\mathrm{n}$, then followed by moring $\operatorname{shift}(\mathrm{M})$ at day $\mathrm{n}+1$.

- Nurse working at night shift $(\mathrm{N})$ at day $\mathrm{n}$, then followed by evening shift (E) at day $\mathrm{n}+1$.

- Nurse working at evening shift (E) at day n, then followed by morning shift (M) at day $\mathrm{n}+1$.

- Day off (O) at day $\mathrm{n}$, then followed by moring shift (M) at day $\mathrm{n}+1$.

- Nurse working at night shift $(\mathrm{N})$ at day $\mathrm{n}$, then followed by night shift $(\mathrm{N})$ at day $\mathrm{n}+1$ and $n+2$.

Nurse work pattern will be checked, if there is a violation of the work pattern then the cost value for $\mathrm{C}_{2}$ is equal to 1 as shown in equation (7).

Where :

$$
C_{2}=\sum_{i=1}^{N} \sum_{j=1}^{D} c x_{i j}
$$

$c x_{i j} \quad$ : costs for working patterns of nurses i. Cost 0 if $\mathrm{x}_{\mathrm{ij}-1} \mathrm{x}_{\mathrm{ij}} \notin\{\mathrm{nm}, \mathrm{ne}, \mathrm{em}$, on $\}$ and $\mathrm{x}_{\mathrm{ij}-1} \mathrm{x}_{\mathrm{ij}} \mathrm{x}_{\mathrm{ij}+1} \notin\{\mathrm{nnn}\}$ else 1

\subsubsection{Soft Constraint}

a. Soft constraints will be explained in this sub-section. The same number of work shifts are maximum of 2 days for morning shift $(\mathrm{M})$, evening shift $(\mathrm{E})$, and day off $(\mathrm{O})$ respectively. By checking the shift pattern, if there is the same shift pattern for three consecutive working days then the value of $\mathrm{C} 3$ is equal to 1 as shown in equation (8).

where

$$
C_{3}=\sum_{i=1}^{N} \sum_{j=1}^{D} c x_{i j}
$$

$c x_{i j} \quad$ : costs for working patterns of nurses i. Cost 0 if $\mathrm{x}_{\mathrm{ij}-1} \mathrm{x}_{\mathrm{ij}} \mathrm{x}_{\mathrm{ij}+1} \notin\{\mathrm{mmm}$, eee, ooo $\}$ else 1

b. Number of each shift and number of holidays for each nurses in a month :

- Morning shift $(\mathrm{M}) \quad: 8$ times.

- Evening shift (E) $\quad: 8$ times.

- Night shift $(\mathrm{N}) \quad: 6$ times.

- Day off $(\mathrm{O}) \quad: 8$ times.

Where $M_{i}, E_{i}, N_{i}, O_{i}$ as the total shift number of (M, E, N, and O) for nurse $i$ in a certain periode and $M_{r e q}, E_{r e q}, N_{r e q}, O_{r e q}$ as the number of shift (M, E, N, and O) required for every

IJCCS Vol. 12, No. 1, January 2018: $21-32$ 
nurses in a certain periode. If $M_{i}, E_{i}, N_{i}, O_{i}$ is not equal to $M_{r e q}, E_{r e q}, N_{r e q}, O_{r e q}$ consecutively, then cost for $\mathrm{C}_{4}$ is equal to 1 as defined in equation (9).

where :

$$
C_{4}=\sum_{i=1}^{N}\left(C M_{i}+C E_{i}+C N_{i}+C O_{i}\right)
$$

$$
\begin{aligned}
& C M_{i}: \operatorname{cost} M \text { for nurse } i, 0 \text { if } M_{i}=M_{\text {req }} \text { else } 1 \\
& C E_{i}: \operatorname{cost} E \text { for nurse } i, 0 \text { if } E_{i}=E_{\text {req }} \text { else } 1 \\
& C N_{i}: \operatorname{cost} N \text { for nurse } i, 0 \text { if } N_{i}=N_{\text {req }} \text { else } 1 \\
& C O_{i}: \operatorname{cost} O \text { for nurse } i, 0 \text { if } O_{i}=O_{\text {req }} \text { else } 1
\end{aligned}
$$

\subsubsection{Mechanisms for Creating New Solutions}

In this study, the initial solution for the nurse's work schedule has been randomly initialized which is represented in $\mathrm{X}$ matrix having $\mathrm{N} * \mathrm{D}$ dimension, where $\mathrm{N}$ is the number of nurses and $\mathrm{D}$ is the number of days, then the number of violations of each constraint will be calculated for initial solution. New solutions is generated by considering the cost matrix, the cost matrix is formed based on the calculation of the constraint violation value and combined with the transition rule. The cost matrix $\mathrm{V}$ with the $\mathrm{N}^{*} \mathrm{D}$ dimension is applied to the initial solution, where the value of cost matrix $\mathrm{V}$ is 0 or 1 . In the initial stage, value of cost matrix is 0 , if there is a violation of the constraint then the corresponding cell value $\left(V_{i j}\right)$ is equal to 1 . A value of 1 in each cell indicates a violation of the constraint. The traditional transition rule is then applied by generating a random new schedule to a cell $V_{i j}$ with a certain probability only if the cell has a value of 1 and is not a work schedule preference request. This transitional rule is applied to create new, more efficient solutions. A block of system processing blocks depicting the activity stages in the process of finding new solutions is shown in Figure 5

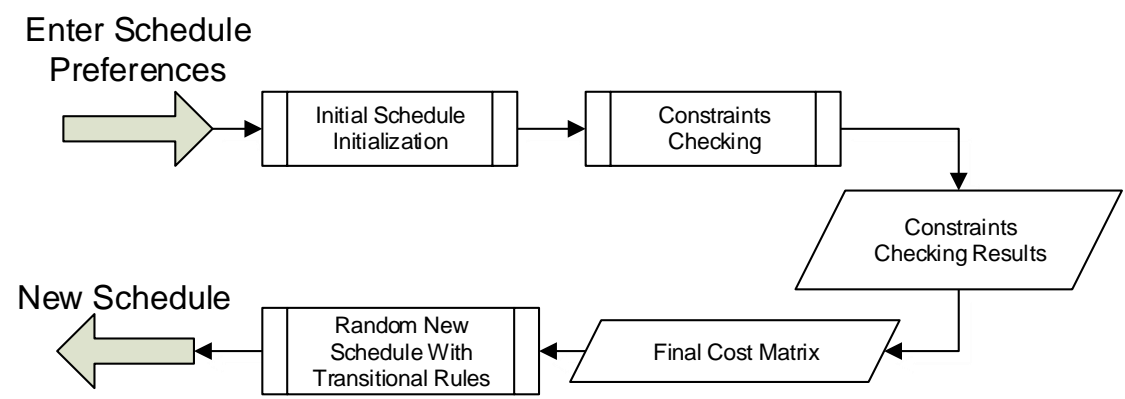

Figure 5 The block diagram searches a new solution

\subsubsection{Cooling Schedule}

Some cooling schemes have been developed such as logarithmic cooling schemes (equation 3) and exponential cooling schemes (equation 4). Logarithmic cooling schedule has been demonstrated to reach global minimum when $=1$ but takes a very long time in the process. In the exponential cooling scheme proved to reach global minimum when $=0.95$ but produces a very rapid temperature drop. In this study a Probabilistic Cooling Scheme (PCS) cooling scheme will utilize the advantages of logarithmic and exponential cooling schemes in equation (10).

$$
T_{k}=\left\{T_{0} \cdot \alpha^{k}\right\} P E+\left\{\alpha \cdot T_{0} / \ln (2+k)\right\} P L
$$

where PE is the probability of the exponential cooling scheme and PL is the probability of a logarithmic cooling scheme. Combination values of PE $\geq 0.3$ and PL $\leq 0.29$. The values of initial temperature, final temperature, and maximum iteration parameters at each temperature is determined based on vary according to the desired conditions. 


\subsubsection{Objective Function}

After $\mathrm{C}_{1}, \mathrm{C}_{2}, \mathrm{C}_{3}$, and $\mathrm{C}_{4}$ is calculated, objective function will be calculated using equation (11). Finally, objective function is a sum of every $\mathrm{C}$ value multiplied by the weight violation constraint.

where :

$$
f=C_{1} \cdot W_{1}+C_{2} \cdot W_{2}+C_{3} \cdot W_{3}+C_{4} \cdot W_{4}
$$

$\mathrm{f} \quad=$ objective function

$\mathrm{C} \quad=$ number of constraints violations

$\mathrm{W}=$ violations weight

\section{RESULTS AND DISCUSSION}

This section presents the results and discussion. Using 12 kinds of test samples, with minimum temperature 20, maximum temperature 70 and 120 with maximum number of iteration 2 and maximum iteration 4 in every temperature decrease. The test results of the PCS cooling method will be compared with the results of logarithmic cooling methods and exponential cooling methods. The results obtained from the test will also be compared against the violation value of the actual work schedule data provided by the hospital.

\subsection{Testing Objective Functions Result}

In this study each hard constraint violation is given a penalty value of 5 and a violation of the soft constraint will cost 3. The temperature drop using the probabilistic cooling scheme (PCS) method with the PE value is 0.3 , alpha 0.95 for the exponential decrease, and the PL value is 0.29 , alpha 1 for logarithmic decrease. The experiments were performed independently, results of an experiment did not affect the results of other experiments.

a. First experiment using minimum temperature 20 and maximum temperature 70 with maximum iteration loop 2. Result of the first experiment shown in Table 1.

Table 1 First Tes result

\begin{tabular}{|c|c|c|c|c|c|c|}
\hline Method & C1 & C2 & C3 & C4 & F Value & Time \\
\hline PCS & 21 & 0 & 0 & 42 & 231 & $15 \mathrm{sec}$ \\
\hline Eksponential & 47 & 0 & 0 & 44 & 367 & $24 \mathrm{sec}$ \\
\hline Logarithmic & 46 & 0 & 0 & 38 & 344 & $28 \mathrm{sec}$ \\
\hline
\end{tabular}

b. Second experiment using minimum temperature 20 and maximum temperature 70 with maximum iteration loop 4. Result of the second experiment shown in Table 2.

Table 2 Second Tes result

\begin{tabular}{|c|c|c|c|c|c|c|}
\hline Method & C1 & C2 & C3 & C4 & F Value & Time \\
\hline PCS & 0 & 0 & 0 & 44 & 132 & $18 \mathrm{sec}$ \\
\hline Eksponential & 68 & 0 & 0 & 45 & 475 & $44 \mathrm{sec}$ \\
\hline Logarithmic & 47 & 0 & 0 & 46 & 373 & $1 \mathrm{~min} 18 \mathrm{sec}$ \\
\hline
\end{tabular}

c. Third experiment using minimum temperature 20 and maximum temperature 90 with maximum iteration loop 2. Result of the third experiment shown in Table 3.

Table 3 Third Tes result

\begin{tabular}{|c|c|c|c|c|c|c|}
\hline Method & C1 & C2 & C3 & C4 & F Value & Time \\
\hline PCS & 30 & 0 & 0 & 43 & 279 & $12 \mathrm{sec}$ \\
\hline Eksponential & 62 & 0 & 0 & 39 & 427 & $38 \mathrm{sec}$ \\
\hline Logarithmic & 38 & 0 & 0 & 41 & 313 & $2 \mathrm{~min} 41 \mathrm{sec}$ \\
\hline
\end{tabular}

IJCCS Vol. 12, No. 1, January 2018: $21-32$ 
d. Forth experiment using minimum temperature 20 and maximum temperature 90 with maximum iteration loop 4 . Result of the forth experiment shown in Table 4.

Table 4 Forth Result Testing

\begin{tabular}{|c|c|c|c|c|c|c|}
\hline Method & C1 & C2 & C3 & C4 & F Value & Time \\
\hline PCS & 18 & 0 & 0 & 44 & 222 & $54 \mathrm{sec}$ \\
\hline Eksponential & 47 & 0 & 0 & 42 & 361 & $1 \mathrm{~min} 40 \mathrm{sec}$ \\
\hline Logarithmic & 36 & 0 & 0 & 41 & 303 & $6 \mathrm{~min} 33 \mathrm{sec}$ \\
\hline
\end{tabular}

From all experiments we got the best value of objective function using PCS cooling method and the worst objective function value using Exponential cooling method. While the fastest process time using PCS cooling method and the longest process time using Logarithmic cooling method. The average value of the objective function of all test results is shown in Figure 6.

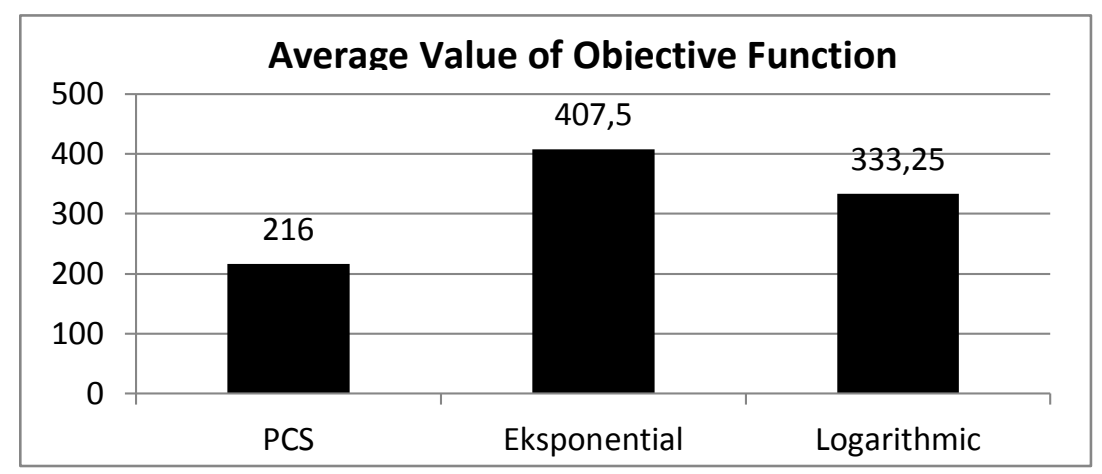

Figure 6 Average value of objective function

The average processing time required for each cooling method is shown in Figure 7.

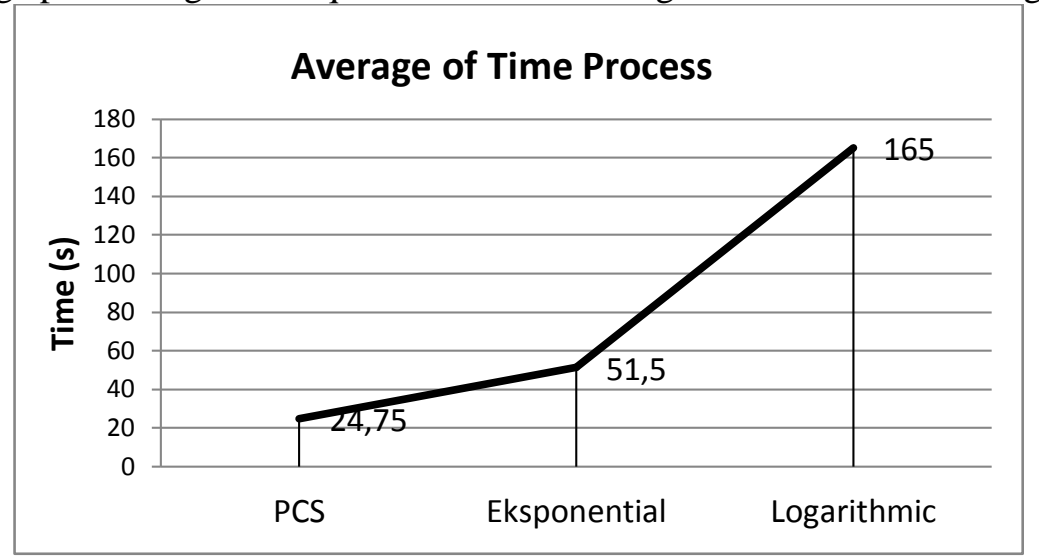

Figure 7 Average time of cooling method

Based on all experiments, the best result is obtained in the second test using PCS method which is then compared with the average of violation of real nurse working schedule in August and September 2016 given by the hospital as shown in Table 5.

Table 5 Result Comparison

\begin{tabular}{|c|c|c|c|c|c|}
\hline Type & C1 & C2 & C3 & C4 & F Value \\
\hline PCS & 0 & 0 & 0 & 43 & 132 \\
\hline $\begin{array}{c}\text { Data from } \\
\text { hospital }\end{array}$ & 29.5 & 0.5 & 28 & 63 & 423 \\
\hline
\end{tabular}


From the comparison results data shown in Table 5, the nurse working schedule generated by the system has a better quality than nurse working schedule created manually.

\subsection{Temperature Decrease Test}

In this sub-section, temperature decrease test is performed. In this experiment the maximum temperature used is 70 and 90 while for the minimum temperature is used 20 for each maximum temperature. Decrease in temperature using 3 types of cooling methods are PCS, exponential, and logarithmic methods.

a. First experiment using minimum temperature 20 and maximum temperature 70

Result graph using minimum temperature 20 and maximum temperature 70 shown in Figure 8.

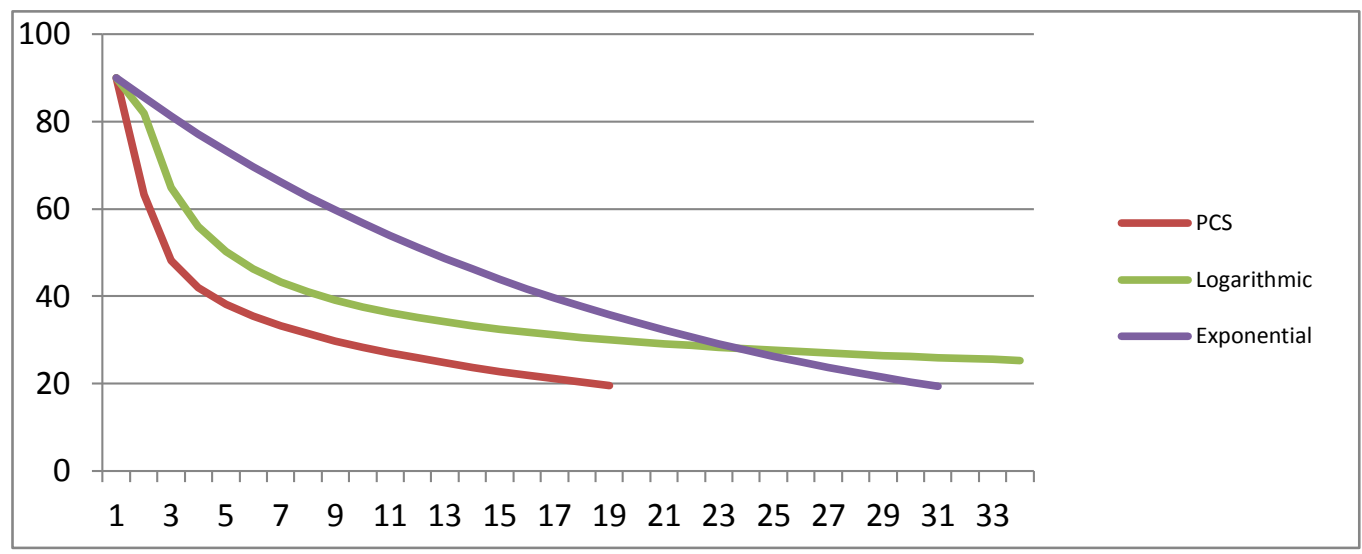

Figure 8 Maximum temperature 70

b. Second experiment using minimum temperature 20 and maximum temperature 90

Result graph using minimum temperature 20 and maximum temperature 90 shown in Figure 9.

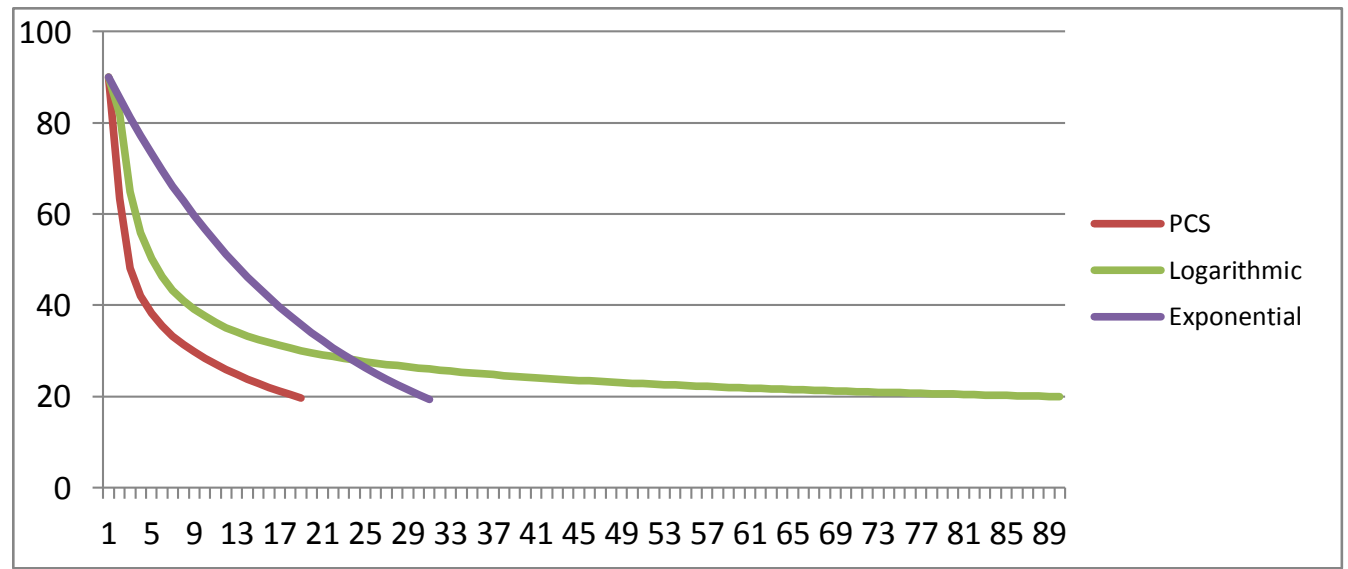

Figure 9 Maximum temperature 90

From two tests result using different maximum temperatures 70 and 90, indicates that the PCS cooling method has decreased faster to reach the minimum temperature, while the longest temperature drop process uses the Logarithmic cooling method.

IJCCS Vol. 12, No. 1, January 2018: $21-32$ 


\section{CONCLUSION}

This system has sucessfully generate a better nurse working schedule solution than manual nurse working schedule. In the best solution there is no violation hard constraint, but on the other test there is a violation on the hard constraint to-1. PCS produces better solution at a faster time than the exponential and logarithmic cooling methods in each test. Increasing the value of the temperature and maximum iteration loop value does not guarantee obtaining a better objective function. The maximum value of the maximum temperature and maximum iteration loop value affect the time required to generate nurse working schedule. In every test the time required always increases if maximum temperature and max loop value increase.

From tests result, nurse working schedule generated by Simulated Annealing algorithm with combination to PCS cooling method and transition rules based on cost matrix have a better solution than manual schedules generated by hospital. The best solution of nurse working schedule shows that there is no violation of the rules set by the hospital in making the work schedule of the 1st hard constraint and the 2 nd hard constraint, as well as the 2 nd soft constraint there is no violation. On the resulting schedule there is only a violation of the second soft constraint.

The application can be developed by adding better transition rules in troubleshooting large solution spaces to meet all hard constraints on each test and produce better objective function values. Combination to other cooling methods can be developed to increase the search time speed with better objective functional value in the process of finding new solutions. For the hospitals the more preference of the nurse's schedule either on leave or work schedule requests on a particular day will increase the value of violation of constraints, as much as possible the schedule preference is minimized to maximize the schedule.

\section{REFERENCE}

[1] S. Toth, "Nurse Rostering," Masaryk University, 2008.

[2] S. Kundu, M. Mahato, B. Mahanty, and S. Acharyya, "Comparative Performance of Simulated Annealing and Genetic Algorithm in Solving Nurse Scheduling Problem," Int. Multiconference Eng. Comput. Sci., vol. I, pp. 19-21, 2008.

[3] E. B. Schlünz and J. H. van Vuuren, "An investigation Into the Effectiveness of Simulated Annealing As a Solution Approach for the Generator Maintenance Scheduling Problem," Int. J. Electr. Power Energy Syst., vol. 53, pp. 166-174, Dec. 2013.

[4] A. I. Diveev and O. V. Bobr, "Variational Genetic Algorithm for NP-hard Scheduling Problem Solution," Procedia Comput. Sci., vol. 103, no. October 2016, pp. 52-58, 2017.

[5] D. Putra and Subanar, "Penerapan Algoritma Genetika Untuk Menyelesaikan Permasalahan Penjadwalan Perawat Dengan Fuzzy Fitness Function," Indones. J. Comput. Cybern. Syst., vol. 6, no. 2, pp. 11-22, 2012.

[6] E. Samana, B. Prihandono, and E. Noviani, "Aplikasi Simulated Annealing Untuk Menyelesaikan Traveling Salesman Problem," Bul. Ilm. Mat. Stat. dan Ter., vol. 3, no. 1, pp. 25-32, 2015.

[7] Suyanto, Algoritma Optimasi Deterministik atau Probabilitik. Yogyakarta: Graha Ilmu, 2010.

[8] R. K. Samuel and P. Venkumar, "Optimized Temperature Reduction Schedule for Simulated Annealing Algorithm," Mater. Today Proc., vol. 2, no. 4-5, pp. 2576-2580, 2015. 
[9] G. V. Gonzales et al., "A Comparison of Simulated Annealing Schedules for Constructal Design of Complex Cavities Intruded Into Conductive Walls With Internal Heat Generation," Energy, vol. 93, pp. 372-382, Dec. 2015.

[10] L. Rosocha, S. Vernerova, and R. Verner, "Medical Staff Scheduling Using Simulated Annealing," Qual. Innov. Prosper., vol. 19, no. 1, pp. 1-11, Jul. 2015. 